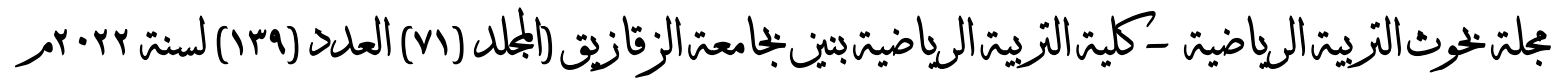

\title{
فاعلية التعلم المعكوس على مخرجات التعلم لبعض مهارات كرة السلة
}

م.د/ محمد محمود عبد القوي

المقدمة ومشكلة البحث:

نظر اً للتقدم الو اسـع في المجال التكنولوجي وخاصة مجال استخدام الحاسوب و البر امج التعليميـة الاكترونية و التي أصبحت من أهم الوسائل التعليمية المستخدمة لتوفير بيئة تعليمية غنية لتخدم التلاميذ عرفو ابالجيل الرقمي، كان لابد من استخدام استر اتيجيات تدريسية منوعة تثير ميول واهتمامات الطلبة

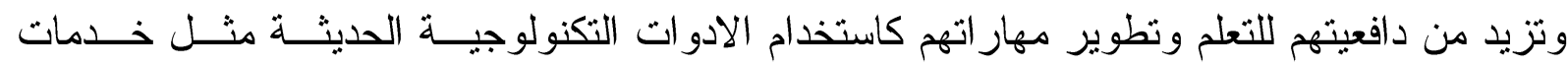
الانترنت ودمجها في عمليتي التعليم والتعلم خاصة وأن الطلبة يعيشون في زمن تتزاحم فيه المعارف وتنتشر بسرعة كبيرة.

ولتحقيق الأهداف التعليمية المرجوة لابد من تتوع أساليب وطرق و استر اتيجيات التدريس التـي يتبعها المعلم, من أجل ذلك أصبح هناك ضرورة لاستخدام الطرق الحديثة بجانب الثــر ح النظــري و النموذج العملي و التي تمكن المتعلم من الفهر الصحيح للأداء ثم الممارسة الصحيحة والوصول للهدف من العملية التعليمية . قد أدي التقدم العلمي إلي إحداث تغيرات جوهرية في كثير من المجالات وشهد النظام التربــوي تطوير في التعليم من حيث أهدافه ومناهجه وذلك حتي يستطيع المتعلم مو اكبة التطور في عصر تسوده تقنيات للنطور السريع في مجال الكمبيوتز و الوسائط المتعددة.(1: • (1)

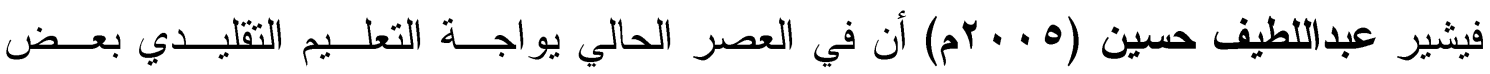
المشكلات مثل (الزيادة السكانية الهائلة) وما نتج عنها من زيادة أعداد المتعلمين، قلة أعداد المعلمــين المؤهلين تزبوياً و التطور المعرفي الكبير ما نتج عنه تشعيب التعليم وعدم در اعاة الفروق الفردية بين المتعلمين فالمعلم يريد إنهاء المقرر الدر اسي في الفترة الزمنية المحددة مما لا يمكن بعض المتعلمـين

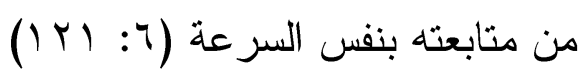
ويرى وليد سالم (11 • r م) أن التعليم الاككتروني أحد المستحدثات التكنولوجية التي ظهرت في الآونة الآخيرة و أثبتت فعالية كبيرة في إكساب التلاميذ المعارف و المهــار ات والاتجاهــات التعليميــة المختلفة، وهذا ما أكد عليه عديد من المهتمين بهذا المجال، ويشير إلى اســتعمال الثقنيــة والوســائل التكنولوجية في التعليم من خلال الاعتماد عليها كأنظمة تعليمية متكاملة وتسخير ها لتعلم الطلبة ذاتيـاً

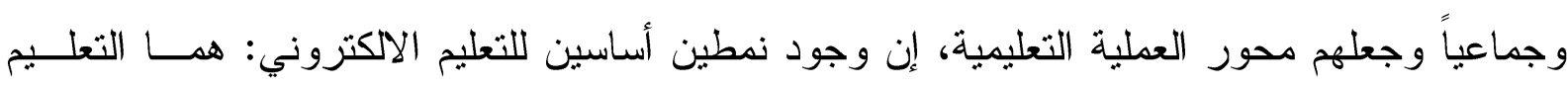

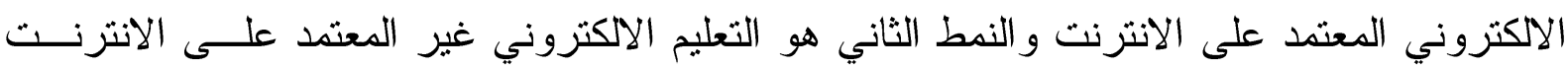
ليتفاعل معها الطلبة في إطار فردي أو جماعي قد يخرج الطلبة من روتين الحفظ و التلقين إلى إثـارة 


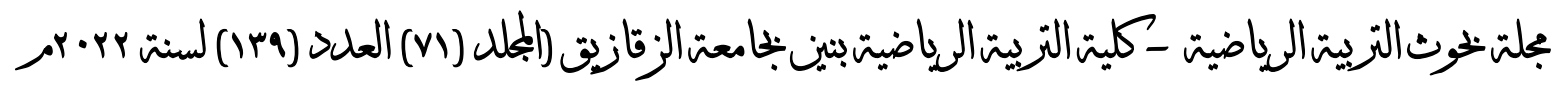

دافعيتهم وزيادة تفاعلهم مع المادة التعليمية مما قد يساعد على تحسين نوعية التعلــيم و الــتعلم. (1)

$(r)-1 V$

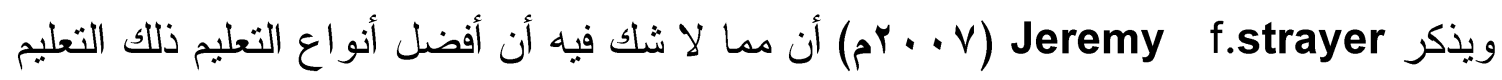

الذي يولد التشوق للمعرفة ويجعل العملية التعليمية أكثر متعه و أكثر حيوية مع قليل من المحاضــرات التقليدية وكثير من المشاريع و القراءات الاطلاع في تعلم يتمركز حول التلميذ لا المعلم ومـــع ازديــاد استخدام التكنولوجيا الحديثة في العملية التعليمية ازدادت أعداد المعلمين الذين يرغبون بتدريس طلابهر

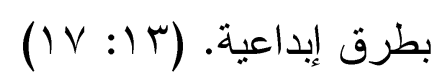

ويعد التعلم المعكوس أحد الحلول التقنية الحديثة لعلاج ضعف التعلم التقلبدي وتتميــة مســتوى

التفاعل ومهار ات التفكير عند الطلاب، فالتعلم المقلوب استراتيجية تدريس تشــمل اســتخدام التقنيـة

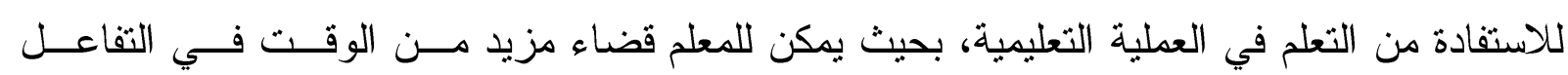
و التعاون و المناقشة مع التلامبذ بدلا من إلقاء المحاضرات، حيث يقوم التلاميذ بمشاهدة عروض فيديو قصيرة للمحاضرات في المنزل، وفي الوقت الأكبر لمناقشة المحتوى في الفصل تحت اشر اف المعلم.

ويري الباحث دخول التكنولوجيا في مجال التعليم جعل دور ها فعال و ايجــابي, ومــن خــلال الاستفادة من تكنولوجيا التعليم في العملية التعليمية وخاصة في الأنشطة الرياضية و الاهتمام بمنــاهج التربية الرياضية يساعد المتعلمين على فهم وإدر الك المهارات الفنية للألعاب الرياضية و إتقانها بصورة وهين فائقة في الجودة.

ويشير كرافورد (Crawford.2015) إلى أن التعلم المعكوس هو قلب الغرفة الصفية إلى مكان

للأنشطة والنقاشات وخاصة من خلال مجموعات الطلبة و هذا يعد تعلماً نشطاً وفاعلا بعد إكمال الطلبة لو اجباتهم المنزلية المعدة من قبل المعلم من خلال حضور محاضرات معدة مسبقاً من خلال الانترنت

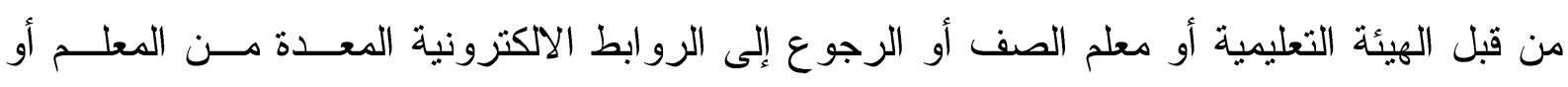

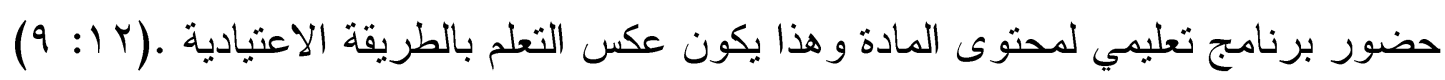

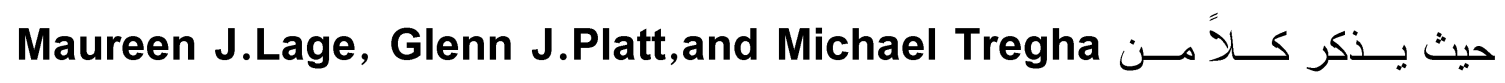

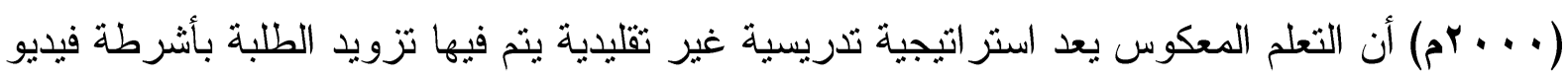

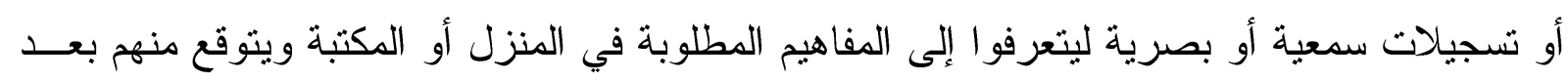

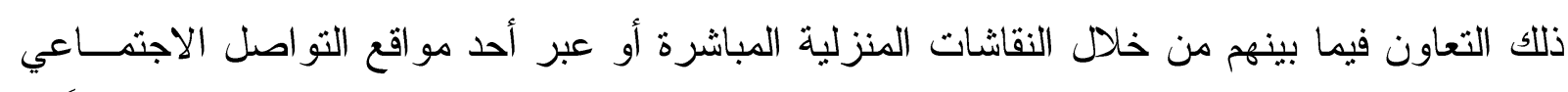

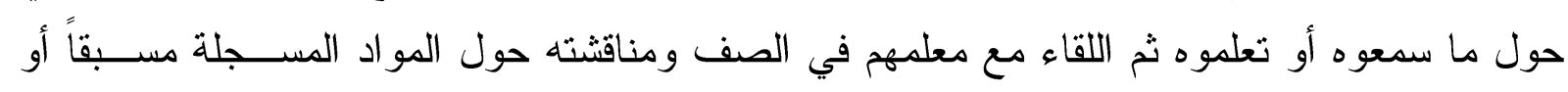
قيامهم بمشاريع جماعية فما هو متاح في الصف في التعليم المعتاد أصبح مناحاً في المنزل في الـتـعلم

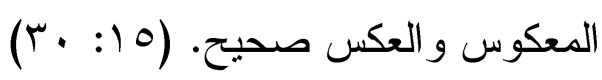




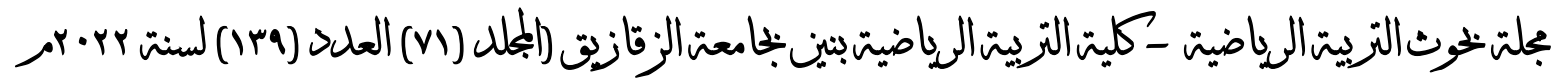

وقد لاحظ الباحث من خلال تدريسه لمقرر كرة السلة وجود نقص في تتوع أساليب التـدريس، و عدم توظيف أدوات التكنولوجيا في العملية التعليمية بشكل كبير، فماز ال عدد كبير مــن المعلمــون وهن يتبعون الطريقة الاعتيادية في التذريس، ومن خلال البحث و الاطلاع وفي حدود علم الباحث أن هـذهـ الدراسات لم تتطرق إلي استخدام هذا الأسلوب ، ولذا اختار الباحث هذا الموضوع لأنه احد التوجهات الحديثة في التدريس ولتطور طرق التدريس لتتاسب التلاميذ في العصر الحديث بعيدا عن الأســاليب

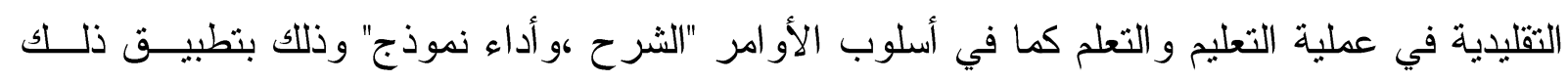
الأسلوب "أسلوب التعلم المعكوس و أثره علي تعلم بعض مهار ات كرة السلة. هدف البحث:

يهدف البحث إلى التعرف علي فاعلية التعلم المعكوس علي مخرجات التعلم لبعض مهار ات كرة السلة وذلك من خلال :

ا - المتغير ات التحصيلية لرياضة كرة السلة للمقرر الدراسي. ץ- تأثير التعلم المعكوس على التحصيل المعرفي وتعلم المهار ات قيد البحث (المحاورة - التصــــيب السلمي -) في كرة السلة.

ب- معدل التغير في التحصبل المعرفي والمستوى المهارى في كرة السلة بين المجموعتين الضـــابطة و التجريبية. فروض البحث :

ا-توجد فروق دالة إحصائيا بين القياس القبلي والبعدي في مستوي التحصيل المعرفي والمتغيـرات المهارية (المحاورة - التصويب السلمي) ولصالح القياس البعدي للمجموعة الضابطة. ץ- توجد فروق دالة إحصائيا بين القياس القبلي و البعدي في مستوي التحصيل المعرفي و المتغيــرات المهارية (المحاورة - التصويب السلمي) ولصالح القياس البعدي للمجموعة التجريبية. ب-توجد فروق دالة إحصائيا بين القياسين البعديين لكلا من المجموعة الضــابطة و التجريبيــة فــي مستوي التحصيل المعرفي و المتغيرات المهارية (المحـــاورة - التصـــويب الســلمي) ولصــالح المجمو عة التجريبية.

\section{المصطلحات المستخدمة في البحث :}

التعلم المعكوس : (المس

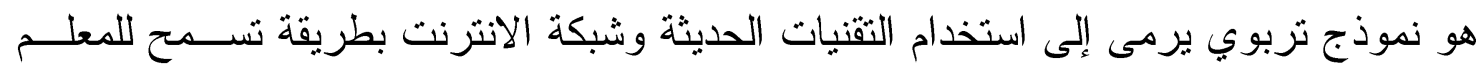

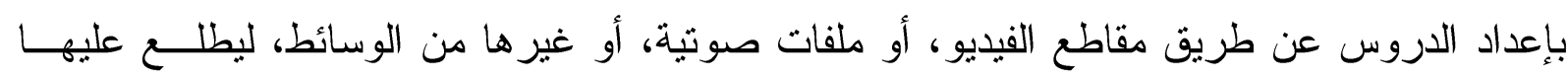

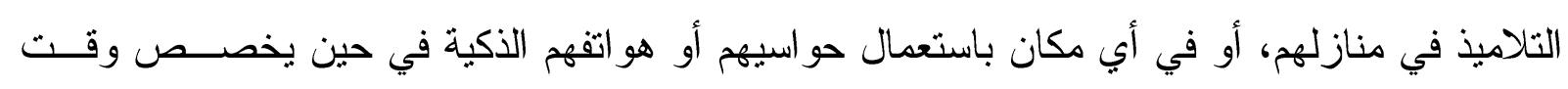
المحاضرة للمناقشات و المشاريع و التدريبات. (90:0؟ 


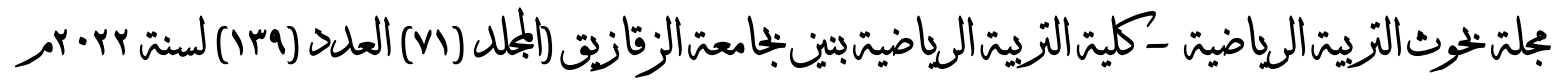

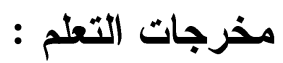

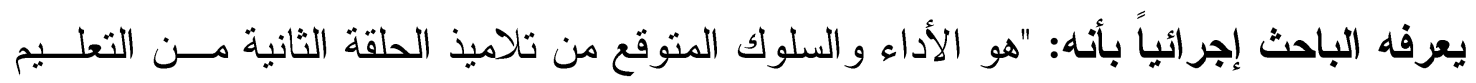

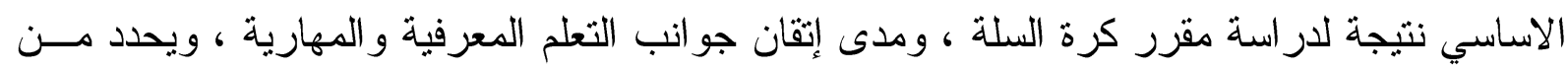
خلال الدرجة التي يحصل عليها التلميذ في الاختبار المعرفي و المهارى". الاراسات المرتبطة المرجعية :

أولا: الاراسات المرتبطة المرجعية العربية:

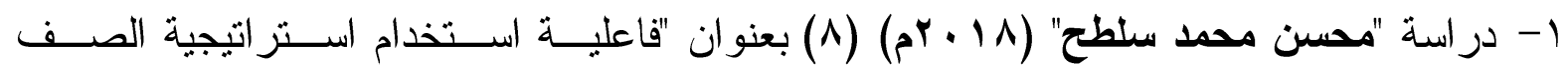

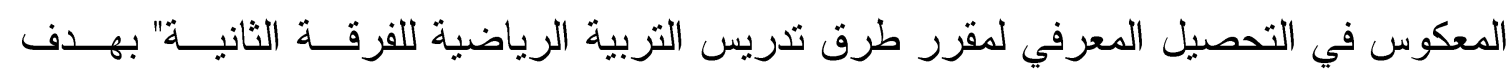

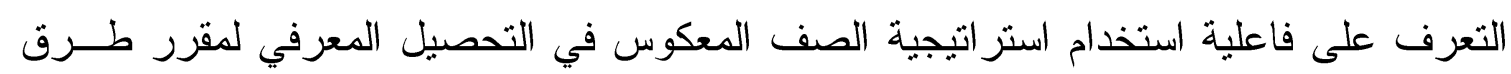
تدريس التربية الرياضية ، واستخدم الباحث المنهج التجريبي و التطبيق القبلي و البعدي علي التبني

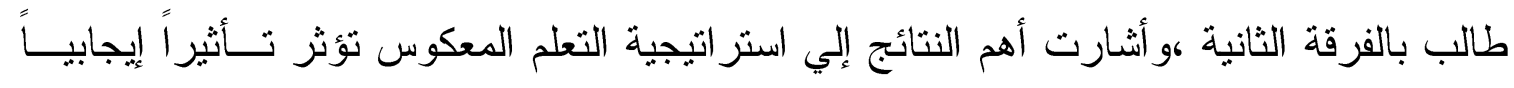

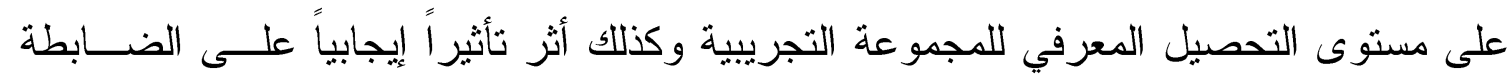
ولكن تأثيره على المجموعة التجريبية كان أعلى من الضابطة.

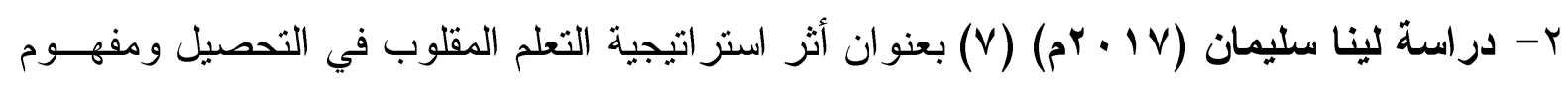

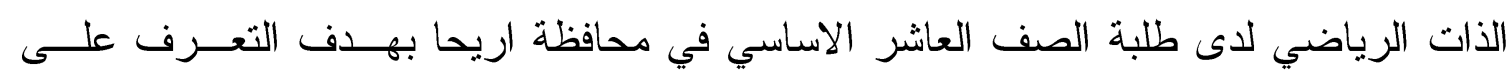

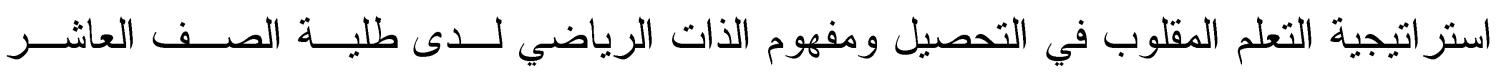

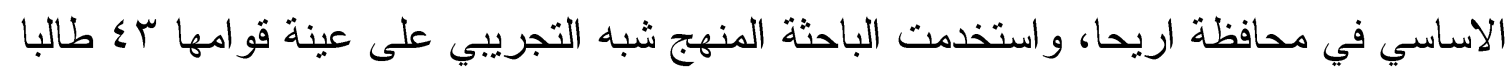

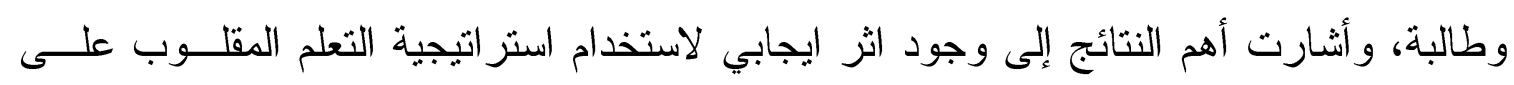

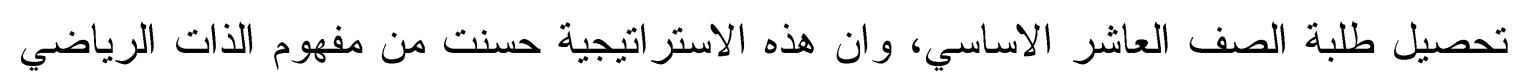
لدى الطلبة و أكسبتهم التقة بقدر اتهم الرياضية.

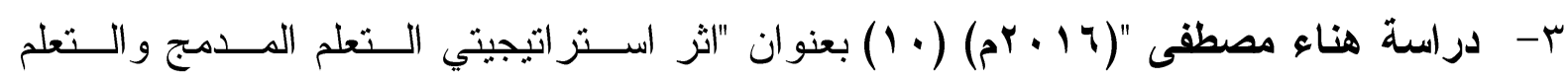

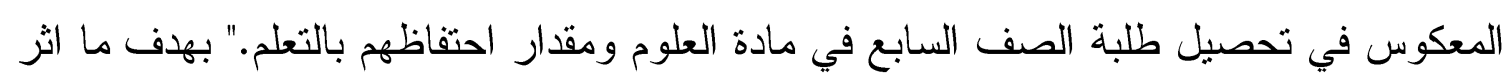

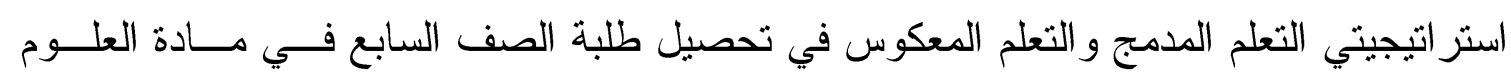

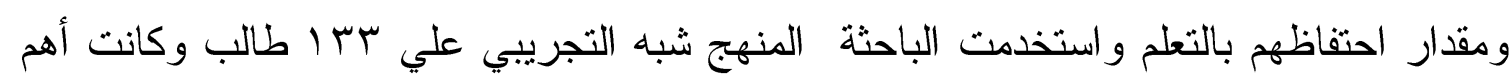

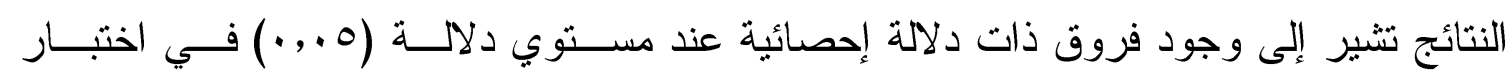
التحصيل المعرفي لصالح المجموعة التجريبية.

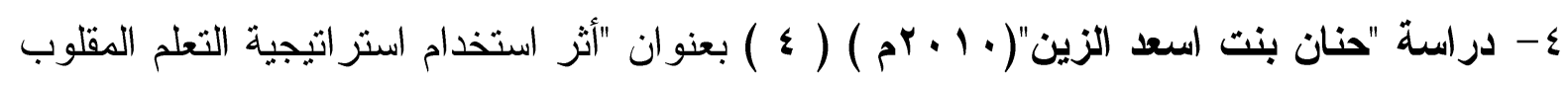

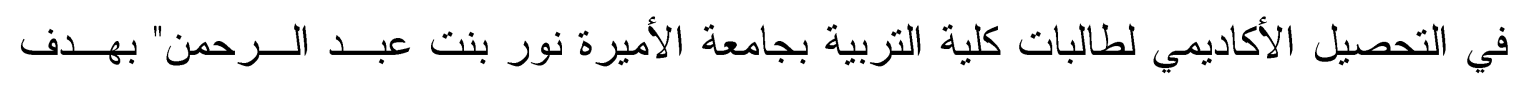

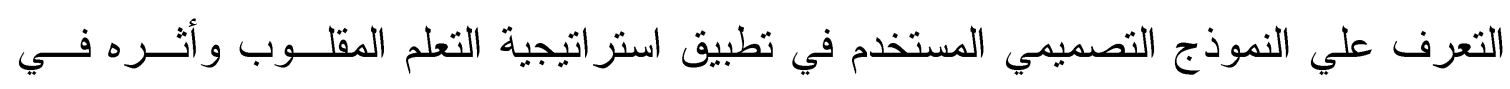




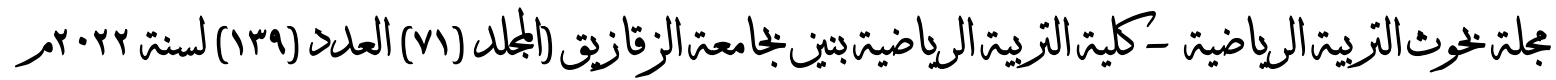

التحصيل الأكاديمي لطالبات كلية التربية، واستخدمت المنهج التجريبي علـي VV طالبــة مــن طالبات كلية التربية في تخصص التربية خاصة و الطفولة المبكرة، وكانت أهــم هـــه النتــائج ضرورة تشجيع المعلمات علي استخدام استر اتيجية التعلم المقلوب وعقــد دورات وورش عمـلـل للمعلمات و الطالبات للتدريب على مفهوم استر اتيجية التعلم المقلوب قبل تطبيقه.

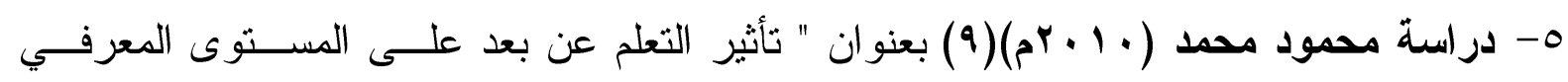
و المهاري لمنهاج كرة السلة" بهدف تصميم موقع انترنت تعليمي و بناء برنامج تعليمي من خلال

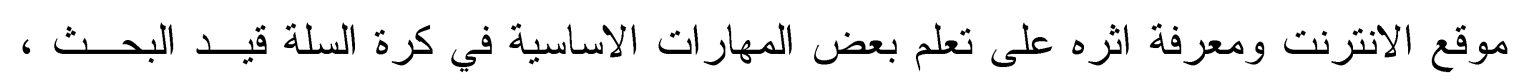

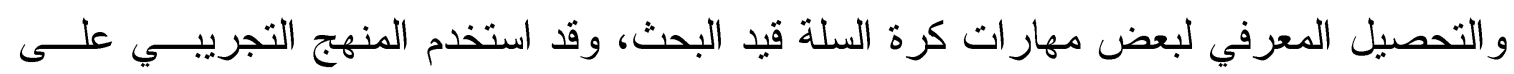
7 ا 11 طالب ، وكانت أهم هذه النتائج ان التعلم من خلال موقع الانترنت التعليمي المقترح ساهم بطريقة ايجابية على آراء و انطباعات افر اد المجموعة التجريبية وفي التعلم والتحصبل المعرفي قيد البحث لأفر اد المجموعة التجريبية أكثر من المجموعة الضابطة.

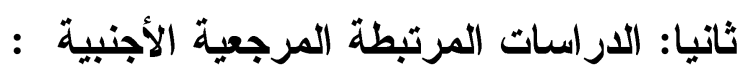
ا-دراسة Stayer,J.F.

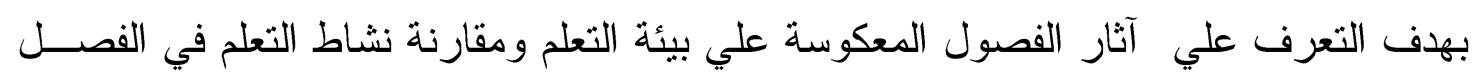
الدر اسي التقليدي وفصول البحث التي تستخدم نظاما تعليميا ذكيا، واستخدم المنهج التجريبـي علي + . . 1 طالب، وكانت أهم النتائج فضل التلاميذ في بيئة الفصل المدروســـة أن الطريقــة أظهرت مستوي أعلي من الابتكار "القدرة على حل المشاكل بطرق مبتكرة وفريدة" و التعــاون الإلمام بالعمل مع الآخرين لحل المشكلات ومناقشة الأفكار" من التلاميذ في الفصل الدراسـي وهي وهي التقليدي تجربة مستوي أقل من توجيه المهام من التلاميذ في الفصل الدراسي التقليدي.

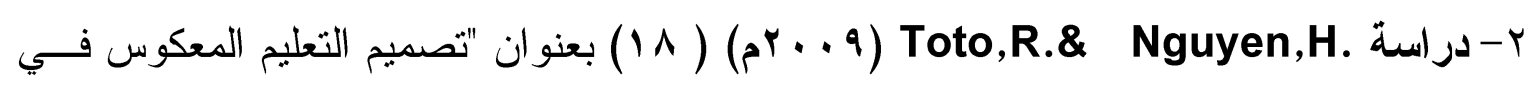
دورة الهندسة الصناعية" بهدف التعرف علي تأثير تصميم التعليم المعكوس في دور الهندســة

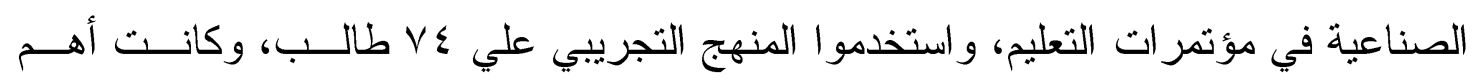
النتائج شعر التلاميذ أن مقاطع الفيديو التي تبلغ مدتها ــ د دقيقة هي الوقت الأمثل لمحاضــرة الفيديو، لاحظ التلاميذ أيضا أنهم شعروا انه من السهل تشتيت انتباههم أثناء مشاهده محاضرة الفيديو، و التلاميذ يقدرون المحاضرات التقليدية وجها لوجه، لكنهم يحبون الفو ائد التي يوفرها الفصل المعكوس من خلال توفير وقت إضافي في الفصل الدر اسي لحل المشكلات و الأنشــطة العملية.

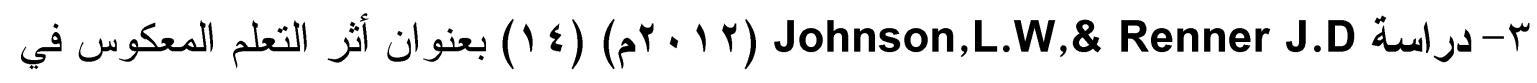
التحصيل ومعرفة اتجاه الطلبة و المعلمين نحوه" بهدف تقصي أثز التعلم المعكوس في التحصيل 


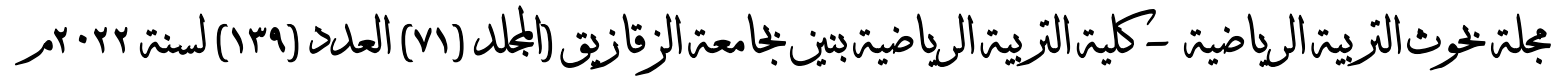

ومعرفة اتجاه الطلبة و المعلمين نحوه، واستخدم الباحث المنهج شبه التجريبي على شعبتين من مدرسة stedy بامريكا ، وكانت اهم النتائج أن لم يظهر تحسناً ملموساً في تحصيل الطلبة في مادة الحاسوب التطبيقي وعزى الباحثان نتائجهما إلى قصور الكفايــات الابداعيــة و الرغبــة القردية عند المعلم.

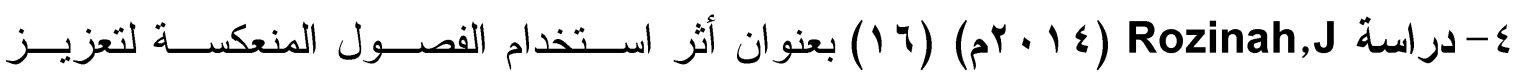
المشاركة وتعزيز التعليم النشط بهدف التعرف على اثز استخدام الفصول المنعكســة لتعزيــز المشاركة وتعزيز التعلم النشط واستخدم الباحث المنهج الوصفي على ؟ب طالب ، وكانت اهم النتائج أن فاعلية استخدام الفصول المنعكسة وتأثثرها على التعلم الذاتي وكانت اعلى الدرجات لصالح المشاركة الوجدانية للطلاب، تليها المشاركة السلوكية ثم المعرفية. خطة وإجر اعات البحث : منهج البحث: استخدم الباحث المنهج التجريبي وذلك لمناسبته لطبيعة الدر اسة، باستخدام التصــميم التجريبـي لمجمو عتين إحداهما تجريبية تستخدم التعلم المعكوس باستخدام الهاتف الذكي في تعلم بعض مهــار ات

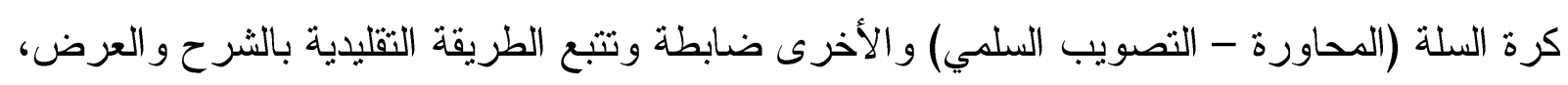
وذلك بإنباع القياس القبلي و البعدي للمجمو عتين • مجتمع البحث : تم إختيار مجتمع البحث من تلاميذ الحلقة الثانية من التعليم الاساسي بمدرسة (الثــــيد محمــــ جمال سليم والتابعة لإدارة غرب المنصورة التحليمية - مديرية التربية والتعليم بالدقهلية للعام الدراسي $(r, r) / a r \cdot r \cdot)$ عينة البحث :

تم اختيار العينة بالطريقة العمدية من تلاميذ الصف الاول وتم اختيار عينة البحـــث بالطريقــة العشو ائية وبلغ عددها ( • ع) تلميذا من تلاميذ الصف الاول الإعدادي .

\section{وتم تقسيمهم الي مجموعتين :}

أ- مجموعة تجريبية و عددها (· (Y) تلميذ وتتبع أسلوب التعلم المعكوس باستخدام الهاتف الذكي في تعلم كلا من الجانب المهاري و المعرفي للمهار ات قيد البحث (المحاورة - التصويب السلمي) ب-مجموعة ضابطة و عددها (·r) تلمبذ وتتبع أسلوب الثرح و العرض في تعلم كلا من الجانب المهاري و المعرفي للمهار ات قيد البحث (المحاورة - التصويب السلمي ) تجانس عينة البحث : 


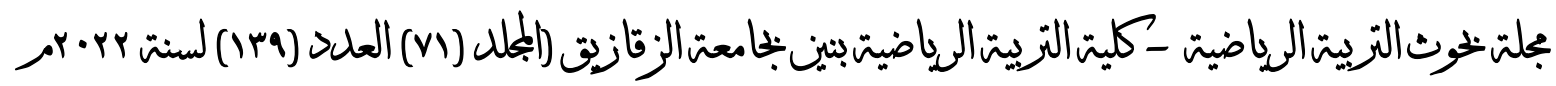

قام الباحث بايجاد التجانس بين أفراد العينة في ضوء المتغيرات الاساسية التي تؤثر علي البحث وهي

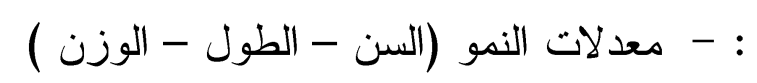

جدول (1)

الالالات الإحصائية لعينة البحث في المتغيرات الأساسية للمجموعة التجريبية والضابطة قبل التجربة . ن

\begin{tabular}{|c|c|c|c|c|c|}
\hline معامل التواء & اللإنحراف المعياري & الوسيط & المتوسط & وحدة القياس & المتغيرات \\
\hline $1.74 \mathrm{~V}$ & $\cdot . \leqslant 1 \leqslant$ & $1 Y .9 V$ & $1 T . Y$ & السنة & السن \\
\hline$\because \vee \leqslant 9$ & $\because \cdot 71$ & $1.0 V 7$ & $1.0 \mathrm{VV}$ & 5 & الطول \\
\hline .040 & $\vee \ldots \wedge$ & $\leqslant 0 . \Gamma_{0}$ & $\leq 7.7$ & كجم & الوزن \\
\hline
\end{tabular}

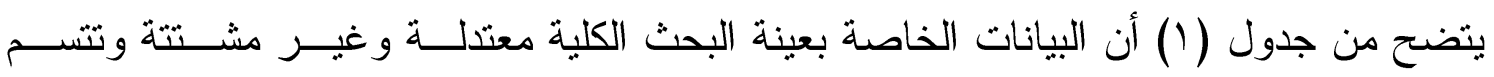

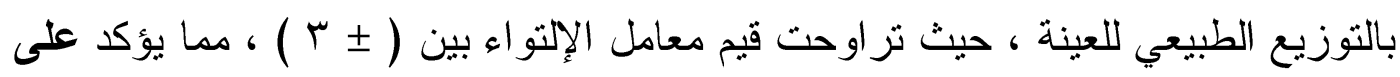

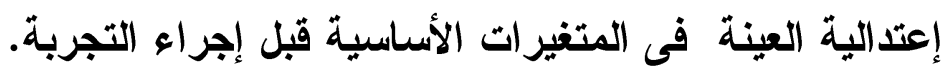

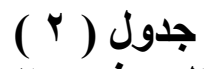

الدلالات الإحصائية لعينة البحث في الاختبار المعرفي و الاداء المهاري للمجموعة التجريبية والضابطة قبل التجربة .

\begin{tabular}{|c|c|c|c|c|c|c|}
\hline التقلطح & الالتواء معامل & الالحعراف & الوسيط & الحسابي & القياس & القياسات \\
\hline 1.1. & $\because V_{-}$ & r.ru & $1 \% .0$. & $1 Y .0$. & لدرجة & الاختبار المعرفي \\
\hline.$\leqslant \mu_{-}$ &.$\leqslant \Lambda_{-}$ &..$\% 0$ & r... & r.q. & متر & الاداء المهاري للمحاورة \\
\hline.$v r$ &.$\Delta r$ & .09 & 0.54 & 0.7. & متر & 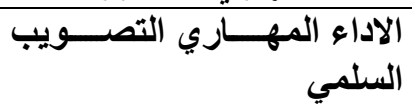 \\
\hline
\end{tabular}

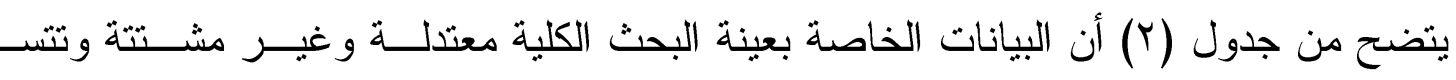

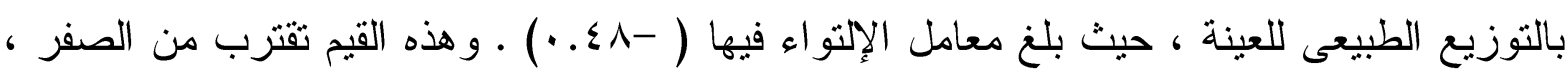

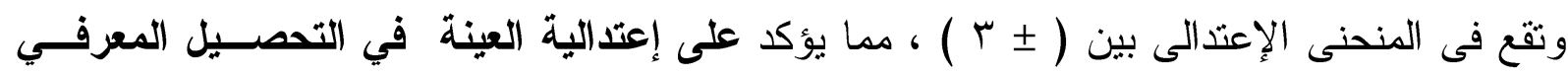

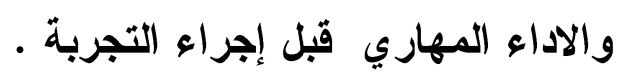
أدوات ووسائل جمع البيانات و اشتملت علي :

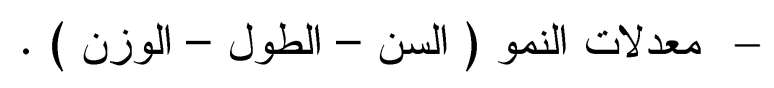

- - إختبار التحصيل المعرفي الخاص بمهارتي المحاورة والتصويب السلمي 


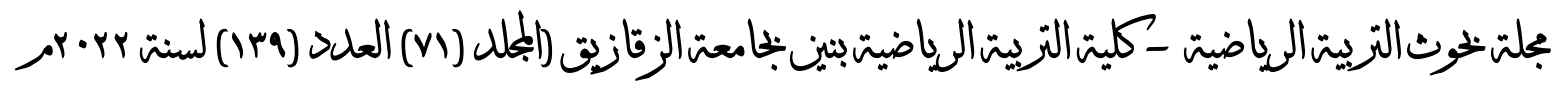

$$
\begin{aligned}
& \text { - - معدات البرنامج التعليمي المقترح. } \\
& \text { معدلات النمو: } \\
& \text { - - العن : تم حساب السن لأقرب سنة. } \\
& \text { - الطول : إستخدام شريط قياس الطول (بالسنتيمتر ). } \\
& \text { - الوزن : إستخدام ميزان طبي لقياس الوزن ( بالكيلو جرام ) }
\end{aligned}
$$

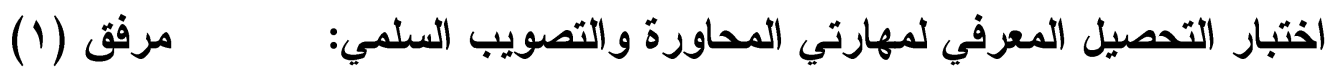

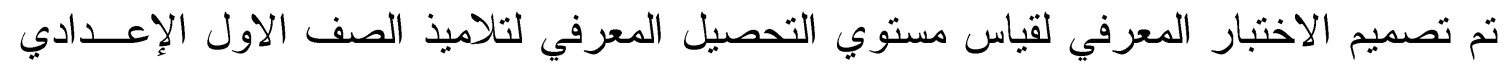

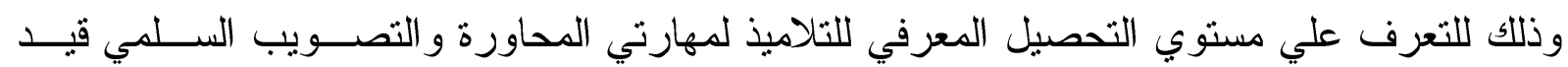

مرفق (r)

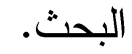
تصميم البرنامج التعليمي باستخدام الهاتف الذكي لتعلم جانبي التعلم المعرفي والمهاري لمهارتي

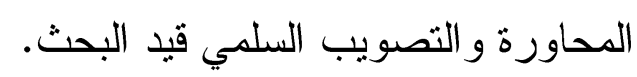

تطبيق البرنامج :

راعى الباحث عند الإعداد لتعليم المهارات قيد البحث النقاط التالية:

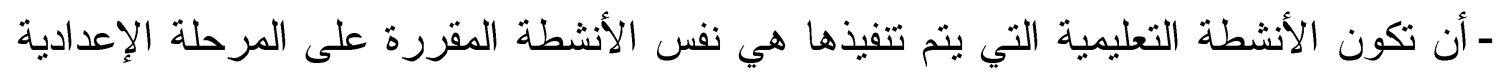

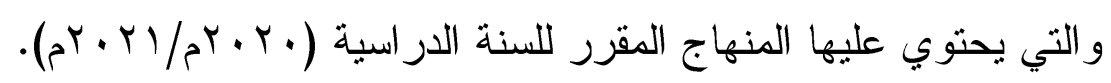
- تدرج الخطوات التعليمية للأنشطة من السهل إلى الصعب ولئه ومن البسيط إلى المركب. - مر اعاة التكرارات وفتر ات الر احة البينية للوصول بأفر اد العينة إلى الحالة الطبيعية.

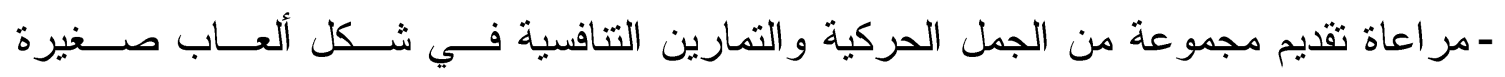

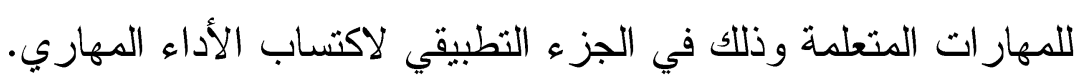
وقد روعي عند التدريس:

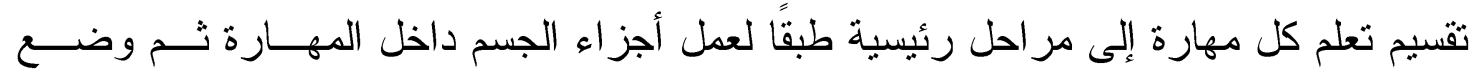
مجموعة من الخطوات التعليمية لكل مرحلة حتى أداء المهارة ككل.

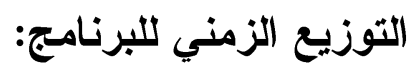

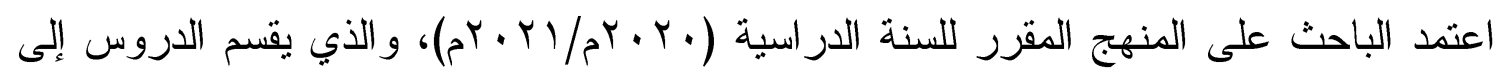

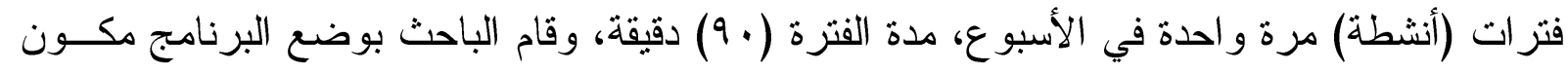

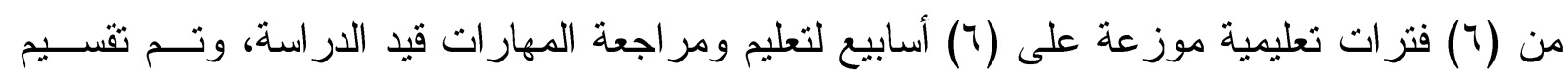

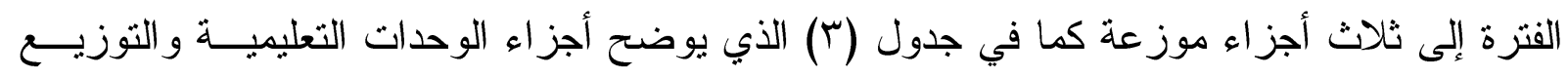

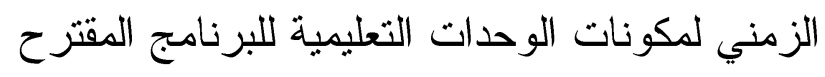




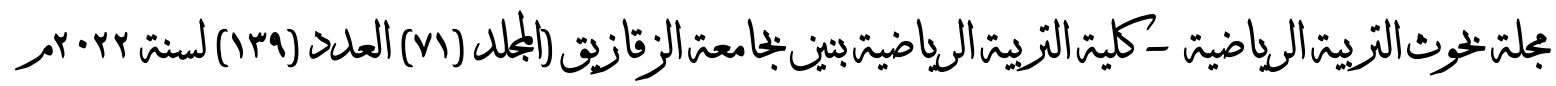

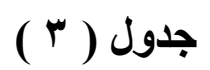

التوزيع الزمني لمكونات الوحدات التعليمية للبرنامج المقترح

\begin{tabular}{|c|c|c|c|}
\hline التقسيم الزمني لأجزاء الفترة & \multicolumn{3}{|c|}{ مكونات الفترة } \\
\hline (ق) 1 • & & التهيئة / الإحماء & \multirow{2}{*}{ التمبه } \\
\hline |0 10 & & الإعداد البدني & \\
\hline (ق) $1 \cdot$ & النشاط المعرفي & \multirow{3}{*}{ مهارة المحاورة } & \multirow{6}{*}{$\overline{7}$} \\
\hline (ق) ${ }^{r} \cdot$ & النشاط التعليمي & & \\
\hline (ق) & النشاط التطبيقي & & \\
\hline (ق) $1 \cdot$ & النشاط المعرفي & \multirow{3}{*}{ 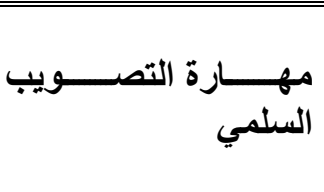 } & \\
\hline (ق) ${ }^{r} \cdot$ & النشاط التعليمي & & \\
\hline (ق) & النشاط التطبيقي & & \\
\hline (ق) & \multicolumn{3}{|c|}{ الجزء الختامي } \\
\hline (ق) 9. & \multicolumn{3}{|r|}{ الإجمالي } \\
\hline
\end{tabular}

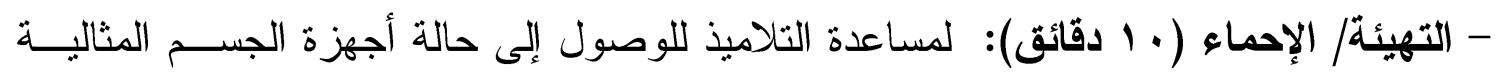
لللاخول في إطار التهيئة الفسيولوجية و النفسية للمشاركة في الأداء.

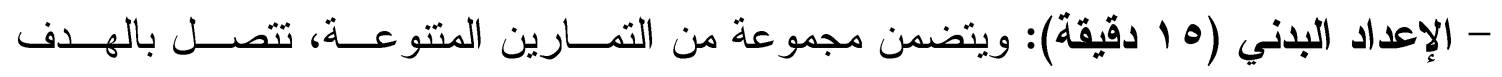

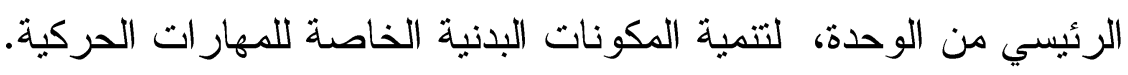

الجزء الرئيسي : ( • آ دقيقة):

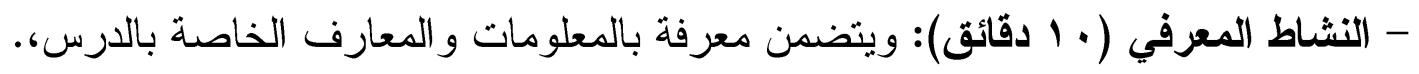

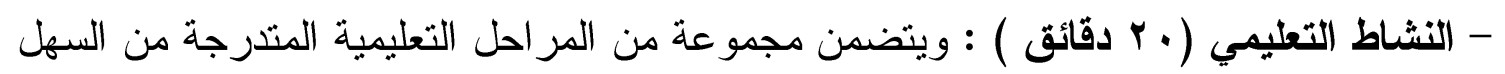

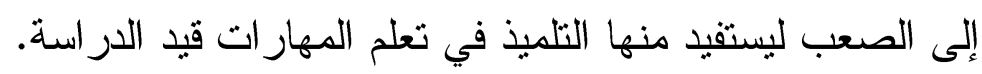

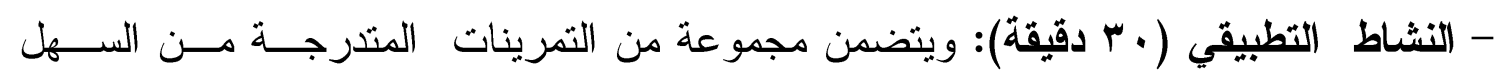
للصعب للإستفادة منها في تطبيق المهار ات. 


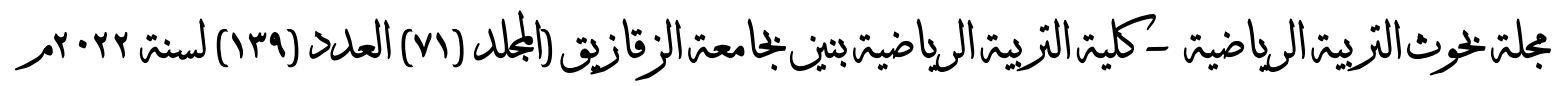

$$
\text { الجزء الختامي : (ه دقائق): }
$$

- التهيئة: تمارين تعمل على تهدئة الجسم وعودته لحالته الطبيعية بالإضافة إلى الجزء النظامي

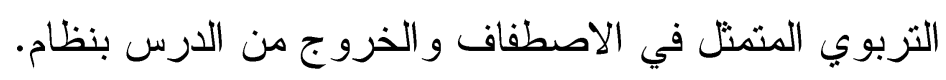

الأدوات والأجهزة المستخدمة في البحث:

الأدوات المستخدمة في البحث:

-كرات سلة، أطو اق، صندوق، شريط قياس، أقماع ، أعلام.

الأجهزة المستخدمة في البحث:

تم استخدام بعض الاجهزة وذلك في القياسات الأنثروبومترية، و واستخدامها في إجراء الاختبار ات

البدنية و المهارية على النحو التالي: ميزان طبي ساعة إيقاف جهاز الريستاميتر.

الخطوات التنفيذية لإجر اءو وتطبيق البحث:-

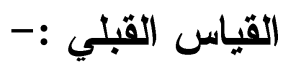

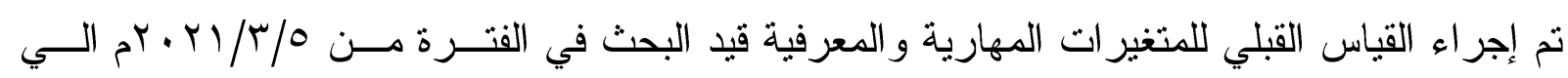

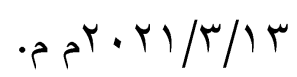

تطبيق التجربة الأساسية :

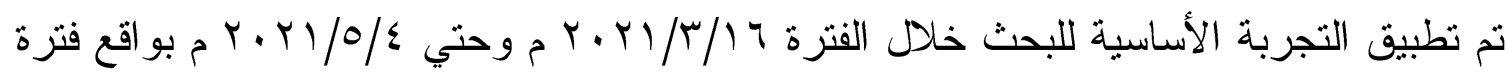

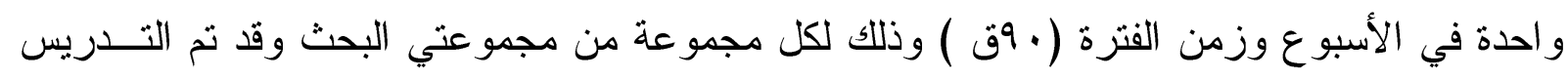

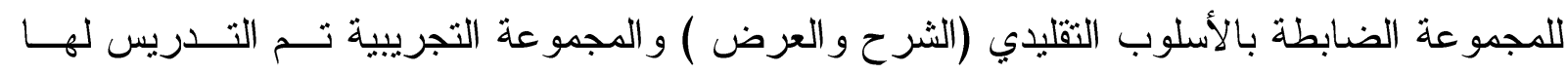

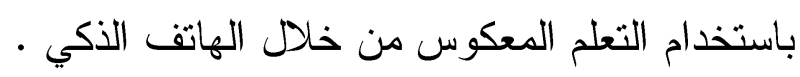

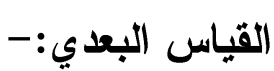

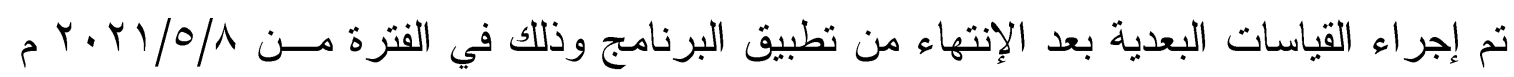

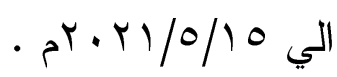
المعالجات الإحصائية المستخدمة في البحث:

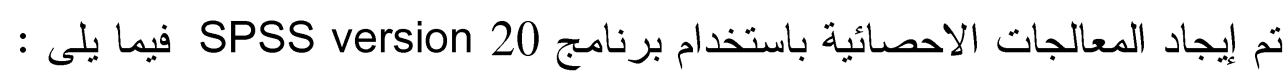

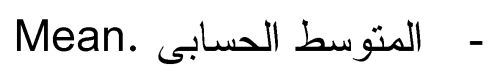

Stander Deviation الإنحر اف المعيارى -

Median -

-

Paired Samples T test. إختبار (ت) لحساب دلالة الفروق للقياسات القبلية البعدية -

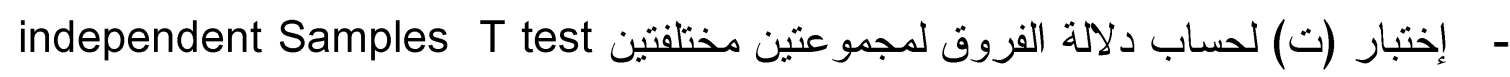




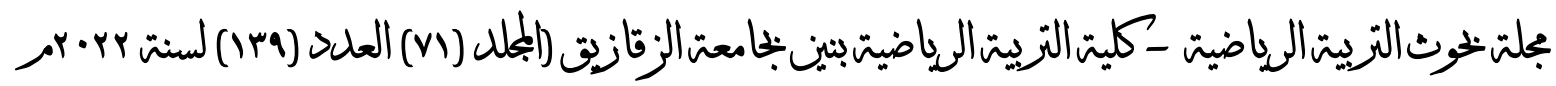
The percentage of improvement \% نسبة التحسن - 


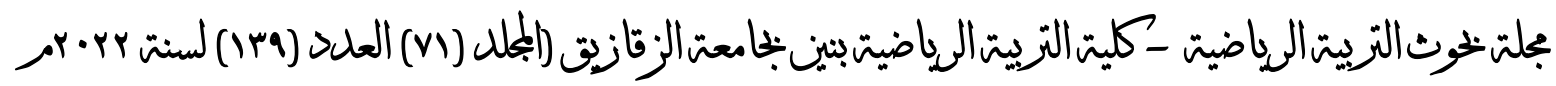

$$
\text { عـرض النتــائج }
$$

\section{جدول ( ع )}

الالالات الإحصائية الخاصة بالاختبار المعرفي والمستوى الرقمي ونسبة التحسن للمجموعة r. الضابطة قبل وبعد التجربة ول

\begin{tabular}{|c|c|c|c|c|c|c|c|c|}
\hline \multirow{2}{*}{$\begin{array}{c}\text { التحسبة } \\
\text { \% }\end{array}$} & \multirow{2}{*}{ قيمة } & \multicolumn{2}{|c|}{ المتوسطين } & \multicolumn{2}{|c|}{ القياس البعدي } & \multicolumn{2}{|c|}{ القياس القبلي } & \multirow{2}{*}{ القياسات الدلالات الإحصائية } \\
\hline & & $\varepsilon^{ \pm}$ & سَ سَ & $\varepsilon \pm$ & سَ سَ & $\varepsilon^{ \pm}$ & سَ - سَ & \\
\hline Th. TV & $* 1.19$ & $\overline{T Y . Y}$ & $\varepsilon .0$ & 1.9. & 17.7 & Y.Is & Ir.o. & الاختبار المعرفي \\
\hline 7. $\wedge$. & $* 9.0 r$ & .1 & $\cdot r \cdot$ & $\cdot r v$ & r. $\varepsilon$. & . ro & r.q. & المستوى الرقمي للمحاورة \\
\hline$\varepsilon . r$. & $* 7 . \leq \varepsilon$ & .17 & $\cdot{ }^{\mu}$ & $.0 r$ & 0.9. & .00 & 0.7. & 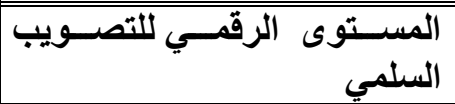 \\
\hline
\end{tabular}

يتضح من الجدول (ع) و الثكل البيانى (1) الخاص بالدلالات الإحصائية الخاصــة بالإختبـار

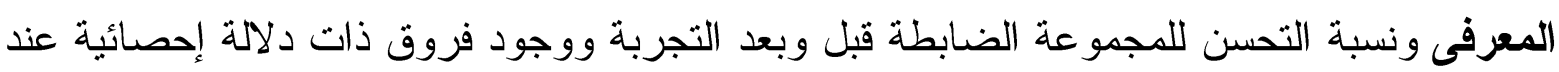
مستوى (0. .•) فى الاختبار المعرفى ، حيث بلغت قيمة ( ت ) المحسوبة فيها (19 (19 ) و هذه القيم

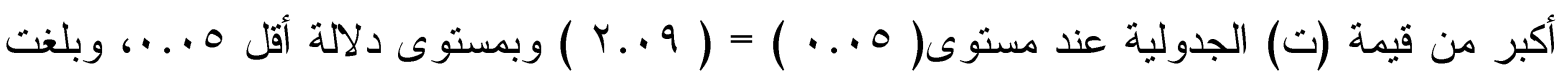

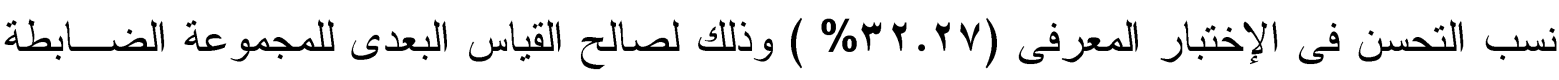

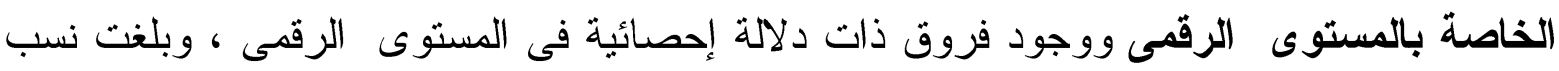

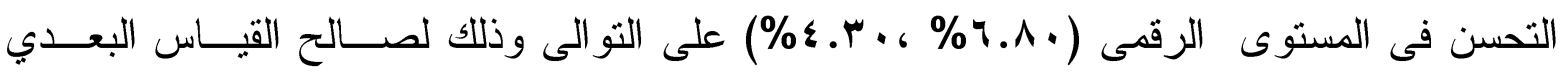
للمجموعة الضابطة.

\section{جذول (0)}

الدلالات الإحصائية الخاصة بالاختبار المعرفي والمستوى (الرقمي ونسبة التحسن للمجموعة r. التجريبية قبل وبعد التجربة

\begin{tabular}{|c|c|c|c|c|c|c|c|c|}
\hline \multirow{2}{*}{ التحسبة } & \multirow{2}{*}{ قيمة (ت) } & \multicolumn{2}{|c|}{ المتوسطين } & \multicolumn{2}{|c|}{ القياس البعدي } & \multicolumn{2}{|c|}{ القياس القبلي } & \\
\hline & & $\varepsilon^{ \pm}$ & سن & $\varepsilon^{ \pm}$ & سَ & $\varepsilon^{ \pm}$ & سَ & \\
\hline$\varepsilon r_{.} \varepsilon$. & $* 11 . \leqslant 4$ & 1.11 & 8.70 & $1.1 \mathrm{~V}$ & $r \leqslant$. & $\overline{Y . Y T}$ & $1 Y .0$. & الاختبار المعرفي \\
\hline $1 . . r$. & $* 17 . r \mu$ & $\because \wedge$ &.$v$. & ס ק. & r.7. & . & Y.q. & المستوى الرقمي للمحاورة \\
\hline $0 . \wedge$. & $* 1.70$ & .10 & $\cdot . r$. & .09 & 7. . . & זי.. & 0.7 & المستوى الرقمي للتصويب السلمي \\
\hline
\end{tabular}




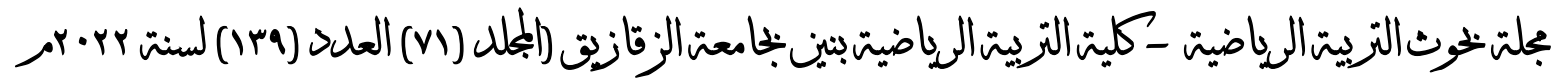

يتضح من الجدول (0) الخاص بالدلالات الإحصائية الخاصة بالإختبار المعرفى ونسبة التحسن للمجموعة التجريبية قبل وبعد التجربة ووجود فروق ذات دلالة إحصائية عند مستوى (0 . •) فـى الاختبار المعرفى ، حيث بلغت قيمة ( ت ) المحسوبة فيها ( آ ـ 11 ) و هذه القيم أكبر من قيمة (ت)

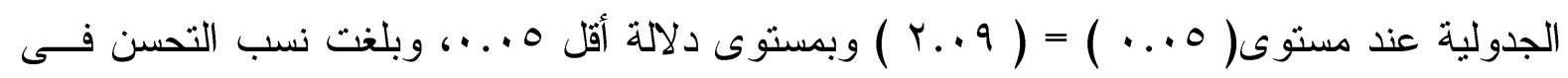

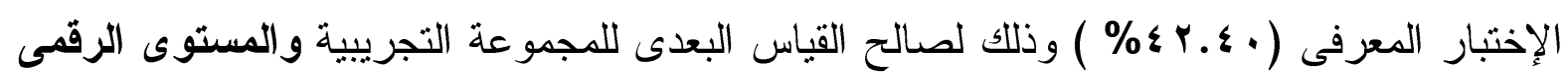
ونسبة التحسن التجريبية قبل وبعد التجربة، وجود فروق ذات دلالة إحصائية عند مستوى (0. . )

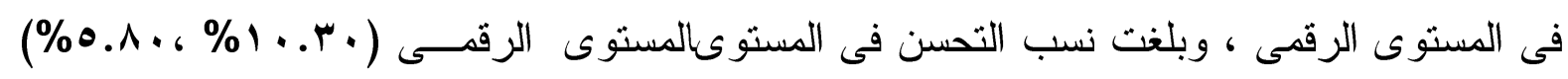
على التو الي وذللك لصالح القياس البعدي للمجموعة التجريبية. جدول ( 7 ( )

الالالات الإحصائية الخاصة بالاختبار المعرفي والاداء المهاري ونسبة التحسن للمجموعة التجريبية والضابطة بعد التجربة الترابة

$\varepsilon \cdot=\dot{0}$

\begin{tabular}{|c|c|c|c|c|c|c|c|}
\hline \multirow{2}{*}{$\begin{array}{c}\text { الفروقة } \\
\text { \% }\end{array}$} & \multirow{2}{*}{ قيمة } & \multirow{2}{*}{ المتربن } & \multicolumn{2}{|c|}{ المجموعة الضابطة } & \multicolumn{2}{|c|}{ المجموعة التجريبية } & \\
\hline & & & $\varepsilon^{ \pm}$ & سَ سَ & $\varepsilon^{ \pm}$ & سَ & \\
\hline $1 \leq . \leq 7$ & $* \varepsilon, \wedge 1$ & r. $\varepsilon$. & 1.9. & 17.7 & $1.1 \mathrm{~V}$ & $r$ r.P. $^{\prime}$ & الاختبار المعرفي \\
\hline $1 Y .9$ & $* r . \wedge$ & $\because \cdot v$ & $\cdot r v$ & r. $\varepsilon \cdot$ & o & r. . . & الاداء المهاري للمحاورة \\
\hline سז.rו & $*$ *I八 & .19 & . & 0.9 & .09 & ૫. $\varepsilon$. & الاداء المهاري للتصويب السلمي \\
\hline
\end{tabular}

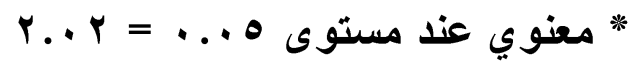

يتضح من الجدول (†) الخاص بالدلالات الإحصائية فـى الإختبــار المعرفـى للمجمــوعتين

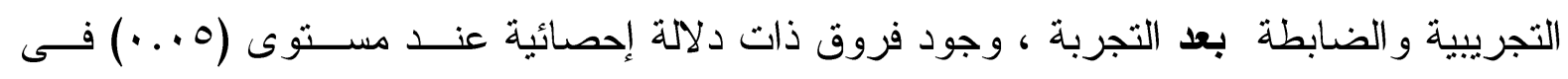

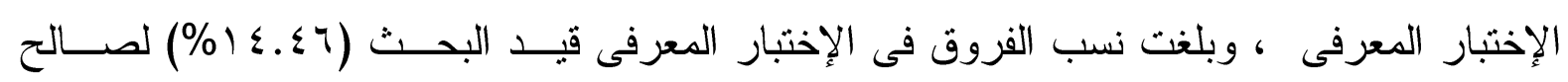
المجموعة التجريبية .المستوى الرقمى للمجموعتين التجريبية و الضابطة بعد التجربة : وجود فروق الإني ذات دلالة إحصائية عند مستوى (0. . •) فى المستوى الرقمى ، وبلغت نسب الفروق فى المستوى بعى

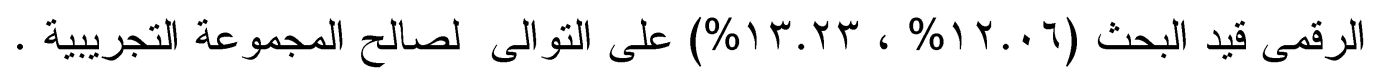
مناقشة وتفسير النتائج يتضح من جدول (ع) الخاص بالدلالات الإحصائية الخاصة بالإختبار المعرفى ونسبة التحسن للمجموعة الضابطة قبل وبعد التجربة وجود فروق ذات دلالة إحصائية فى الاختبار المعرفى وبنســب بــ 


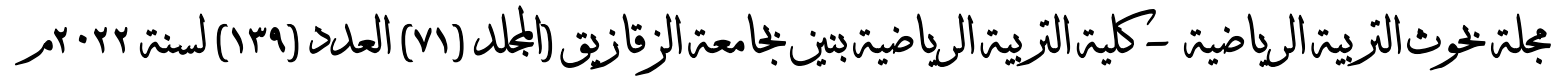

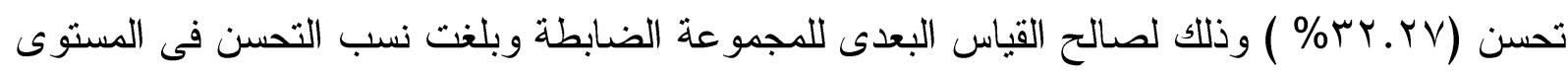

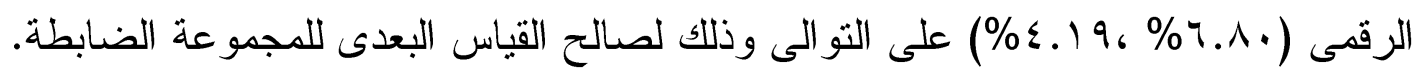

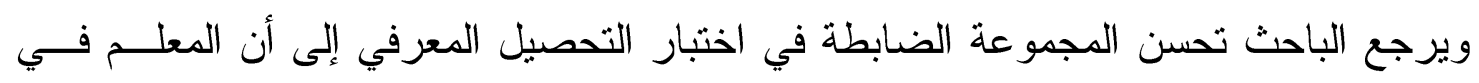
أسلوب الشرح و عرض النموذج يقوم بتقديم المعارف و المعلومات عن مسابقات كرة السلة وخاصة عن

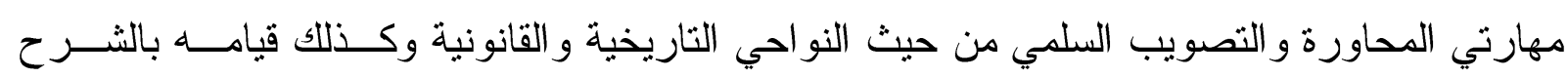
اللفظي لطريقة الأداء الفني للمهارة المر اد تعلمها و تكر اره لهذه المعارف و المعلومــات عـدة مـــرات و المعلومات الخاصة بمسابقات كرة السلة عامة ومهارتي المحاورة و التصويب السلمي بصورة جيدة . كما يرى الباحث أن التقدم الحادث في القياس البعدي للمجموعة الضابطة عن القياس القبلي فى المستوي الرقمي ، أنه قد يرجع إلى الطريقة التقليدية (الثرح و العرض ) للمجموعة الضابطة والتـي

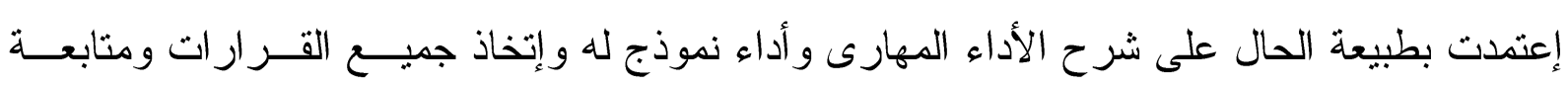
المتعلمين و إصلاح الأخطاء مع تكرار الأداء لتدريبات المهار ات.

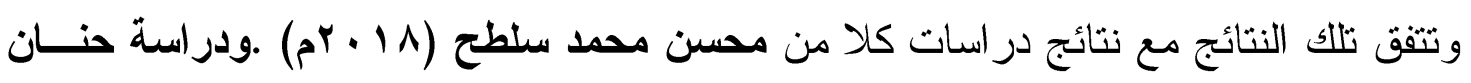

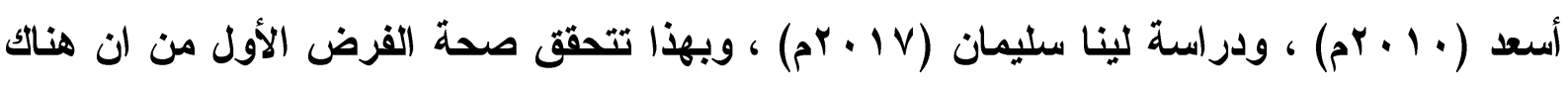
فروق ذات دلاية احصائية بين القياسين القبلي والبعدي للمجموعة الضــابطة فــي نتــائج اختبـار التحصيل المعرفي والمتغيرات المهارية لكل من مهارتي البحث (المحـــاورة والتصــويب الســلمي) و(لصالح القياس البعدي)

يتضح من الجدول ( 0 ) وجود فروق دالة إحصائيا بين متوسطات درجات القياسات القبليــة والبعدية للمجموعة التجريبية (التعلم المعكوس) في إختبار التحصيل المعرفي ولصالح القياس البعدى مما يشير إلى أن البرنامج التعليمي المقترح قد أثر ثأثثراً إيجابياً على مستوى التحصــيل المعرفيـي لتلاميذ المجمو عة التجريبية . ويرى الباحث أن تلك الفروق بين القياسين للمجموعة التجريبية في اختبار التحصيل المعرفي إلىى استخدامهم برنامج التعلم المعكوس و الذي تقدم فيه المعلومات مقترنة بالوسائل التوضيحية لها مما تؤدى إلي التر ابط بين المعلومات المقدمة في أشكال متعددة من (نصوص وصوت ورســوم وصـــور

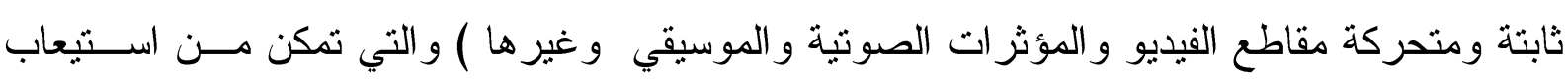

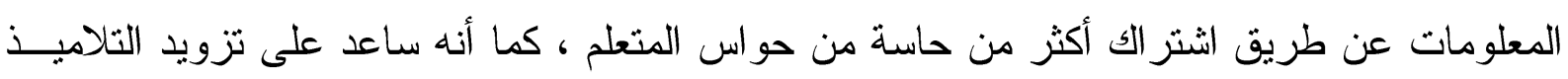
بالمعارف و المعلومات عن المحاورة و التصويب السلمي من حيث النواحي التاريخية و القانونية وكذلك النواحي الفنية و التعليمية الخاصة للمحاورة و التصويب السلمي بالإضافة إلى العرض المنظم و المشوق لكل هذه المعارف و المعلومات . 


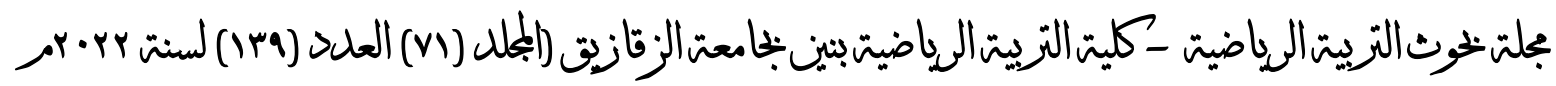

ويرجع الباحث حدوث فروق ذات دلالة إحصائية لتلاميذ المجموعة التجريبية بـين القياســات

القبلية و البعدية في المستوي الرقمي إلى المتغير التجريبي الذى يتمثل في البرمجية التعليميــة المعـدة ببرنامج التعلم المعكوس والتي تؤدى إلى خلق بيئة تعليميه تشجع على التفكير العلمي كما أن الأسلوب

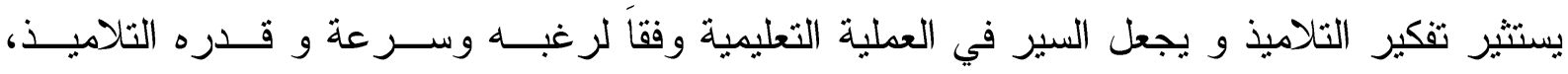
ويشعر هم برنامج التعلم المعكوس (كأسلوب للتدريس) بقيمتهم ودور هم في الإدر الك الذاتي دون مساعدة المعلم، مما أدى إلى استيعابهم المهار ات قبد البحث بصورة أفضل؛ وذلك لأنه ساعد التلاميذ أيضا على الفهم الجيد للمهار ات و استبعابها بصورة أفضل، كما أنه أدى إلى تتمية الجوانب المعرفية الخاصة بها مما ساهم في تحسن الأداء المهاري للتناميذ في المهار ات قيد البحث . ويرجع الباحث الفرق بين القياسين القبلي و البعدي للمجموعة التجريبية في الاداء المهاري إلى أن تأثير برنامج التعلم المعكوس كان تأثيرًا إيجابيًا، حيث احتوى البرنامج على مجموعة من لقطـات الفيديو و الصور الثابتة و المتحركة و النصوص و التمرينات البدنية المتنوعة والتي ساعدت علي إيقـاء أثر التعلم لفترة طويلة، وكذلك جذب انتباه التلاميذ والمشاركة الإيجابية و التفاعل بين المادة التعليميــة و التلميذ، وطريقة عرض المادة مما ساعد في بذل الجهد في الأداء بصــورة مختصــرة، و البرنــامج المعرفي باستخدام الهاتف المحمول أثر كتغذيه راجعه خارجية تأثيرًا إيجابيًا في التعلم.

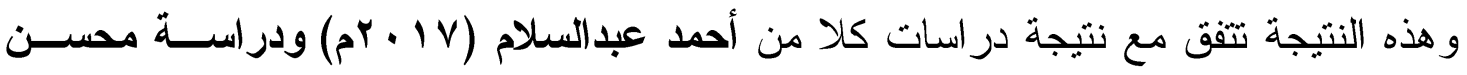

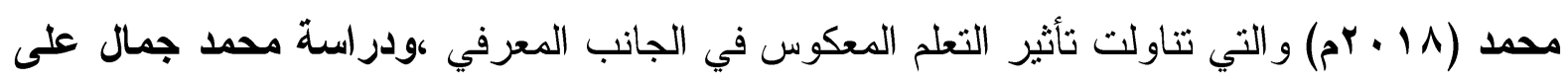
فرج (1 1 • rم) والتي تتاولت تأثير التعلم المعكوس علي أنشطة التربية الرياضية . وبهذا تتحقق صحة الفرض الثاني من ان هناك فروق ذات دلامة احصائية بين القياسين القبلي والبعدي للمجموعة التجريبية في نتائج اختبار التحصيل المعرفي والمتغيرات المهاريــة لكـلـ مــن مهارتي البحث (المحاورة والتصويب السلمي ) و(لصاتح القياس البعدي)

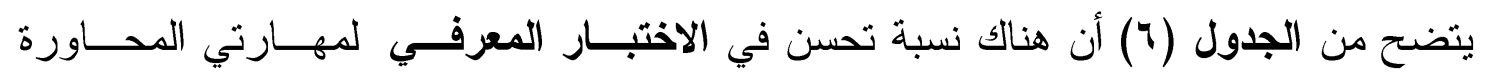
و التصويب السلمي و المستوي الرقمي وذلك لصالح المجموعة التجريبية التي استخدمت التعلم المعكوس باستخدام الهاتف الذكي و هذه النتيجة تتفق مع نتائج دراسة أحمد عبد المنعم عبد البـاقي (r ا • r م) ودراسة لينا سليمان (V V • r م) و التي أثنارت الي التأثير الإيجابي لبرنامج التعلم المعكوس علي تعلم الانشطة الرياضية .

ويرجع الباحث السبب في ذلك في أن استخدام أساليب تكنولوجيا التعليم ومنها التعلم المعكوس تمثل شكلا من أشكال التفاعل المنظم بين مجموعة من الوسائل التعليمية التي تسمح لكل متعلم أن يسير في البرنامج التعليمي وفقاً لخصائصه الذاتية من أجل تحقيق مجموعة من الأهداف التي تركز عليهــا عملية التعلم، ويساعد استخدام برامج التعلم المعكوس على التوجيه الذاتي للمتعلم وإيجابية في التفاعل 


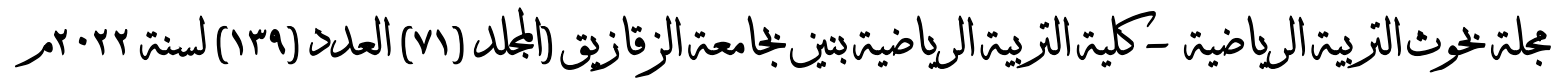

و العمل مع بيئته التطبيقية بطريقة إيجابية، مما يخلق لدية الانتباه و الأثارة و السعي إلى الوصول إلـى المعلومة مما يؤدى إلى استيعاب المهار ات بشكل إيجابي وبالتالي تزيد لديه الرغبة و الميـلـل و الاتجـــاه نحو ممارسة مسابقات كرة السلة .

وبهذا تتحقق صحة الفرض الثالث من ان هناك فروق ذات دلامة احصــائية بـين القياسـين البعديين للمجموعتين الضابطة والتجريبية في مستوى التحصيل المعرفي والمتغيرات المهارية لكل من مهارتي البحث (المحاورة والتصويب السلمي ) و(لصالح المجموعة التجريبية)

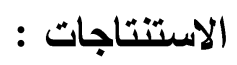
في ضوء مجال البحث و الهدف منه ، و استتاداً على ما تم من إجر اءات ومعالجات إحصائية، وفـى :

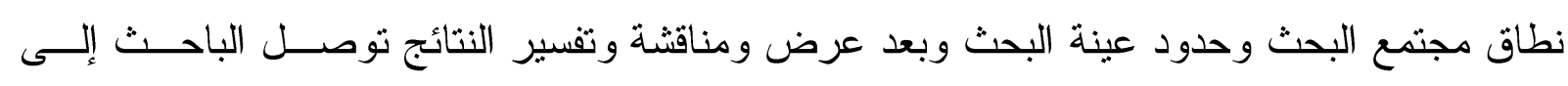

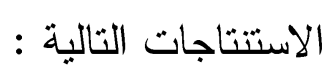
ا - فعالية استر اتيجية التعلم المعكوس على زيادة مستوى التحصيل المعرفي لمهـــارتي المحــاورة و التصويب السلمي. ץ- البرنامج التعليمي المعكوس باستخدام الهواتف الذكية ساهم بطريقة إيجابية في تتمية المستوى

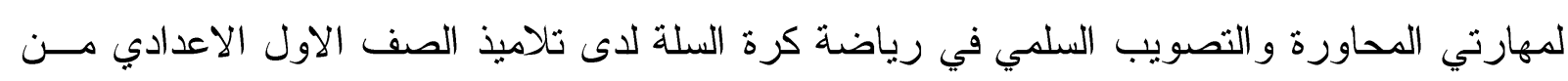
التعليم الاساسي بادارة غرب المنصورة التعليمية التابعة لمحافظة الدقهلية.

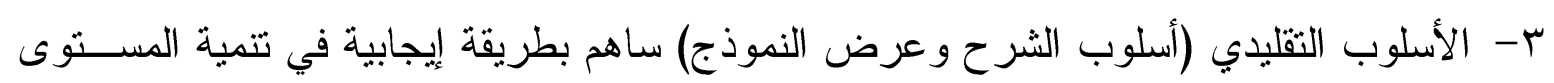
البدني و التحصيل المعرفي لكل من مهارتي المحاورة والتصويب السلمي لتلاميذ المجموعة الضابطة.

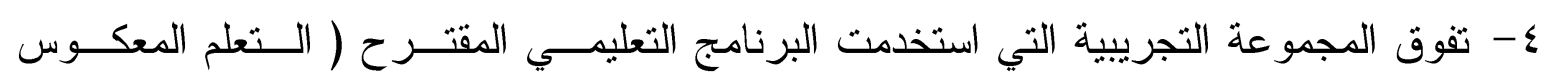
باستخدام الهاتف الذكي) على المجموعة الضـابطة التي استخدمت الاسلوب التقليدي (أســلوب الثــرح و عرض النموذج) ه- سهولة تطبيق برنامج التعليم المعكوس وجذب المتعلمين لله خلال مر احل التعليم التوصسـيات : (التوبات طبقاً لما أشارت إليه المعالجات الإحصائية وما تم التوصل إلبه مــن اســتنتاجات أمكـن تقــديم التوصيات الآتية: ا-نشر ثقافة التعلم المعكوس لدوره في جذب المتعلمين في تتمية الاداء المهاري و التحصيل المعرفي في مختلف المو اد الدر اسية. ץ- تعميم البرنامج التعليمي المقترح باستخدام التعلم المعكوس في تتمية الاداء المهــاري و التحصــيل المعرفي لكل من المحاورة و التصويب السلمي. 


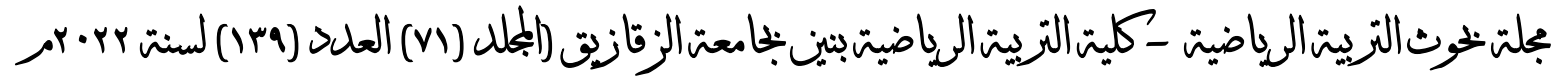

r- ضرورة تأهيل معلم التربية الرياضية في التكنولوجيا حتى يستطيع التعامل مع الأجهزة والأدوات الحيثة في مجال تكنولوجيا تدريس التربية الرياضية.

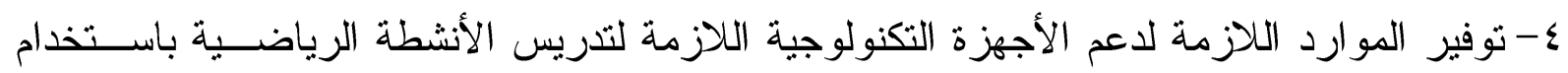

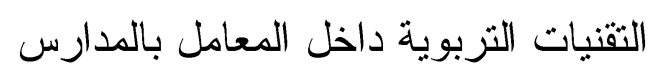

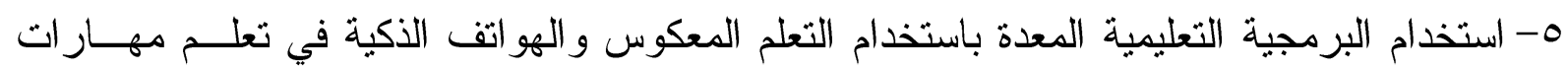

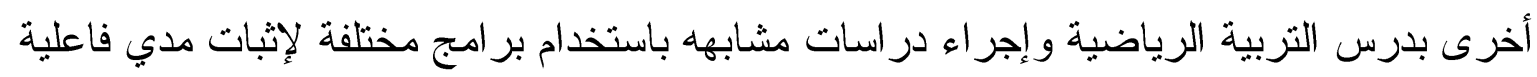

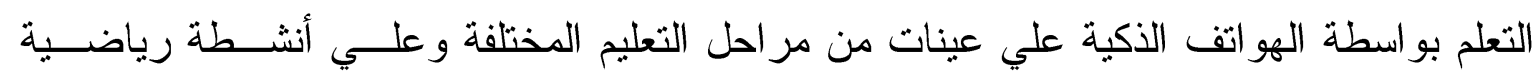

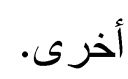

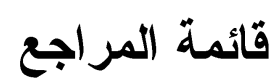

أولاً : المراجيع العربية العراية

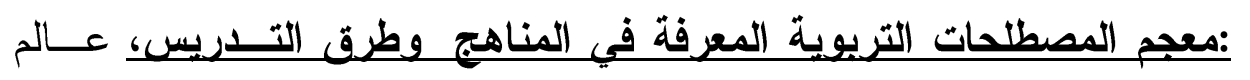

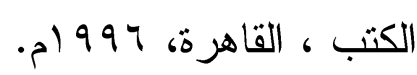

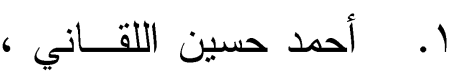

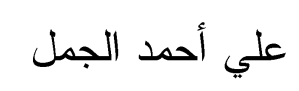

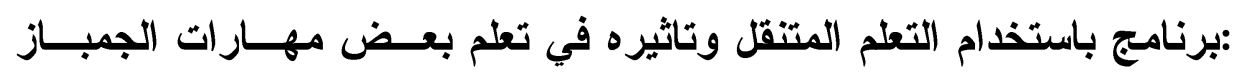

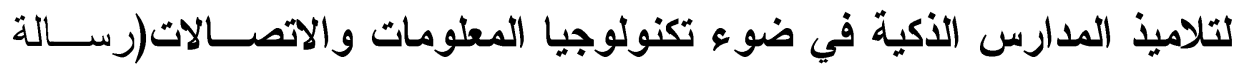

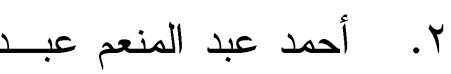

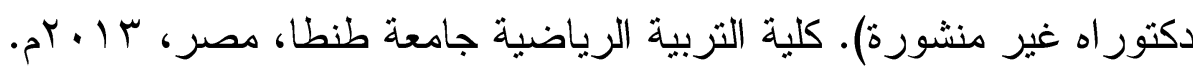

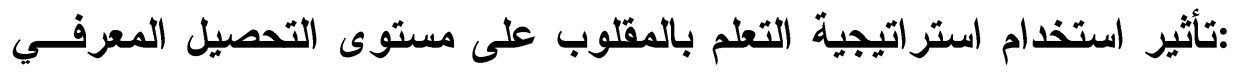
r. - إيمان إبر اهيخ مبروك

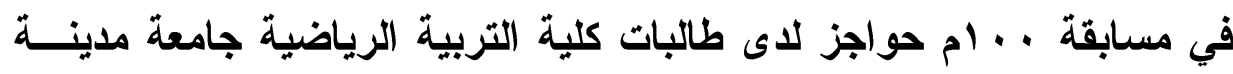

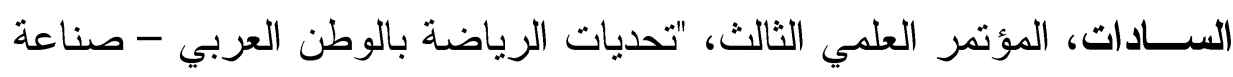

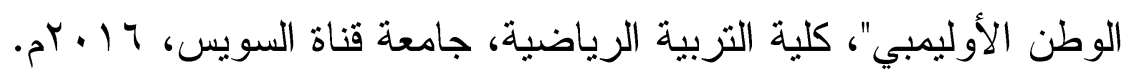

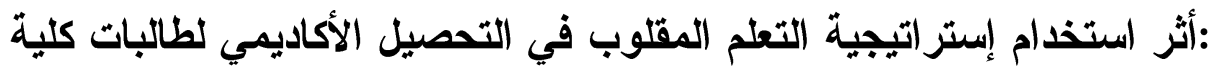

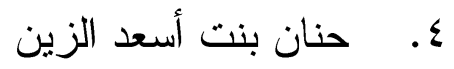

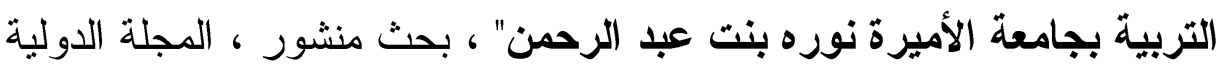

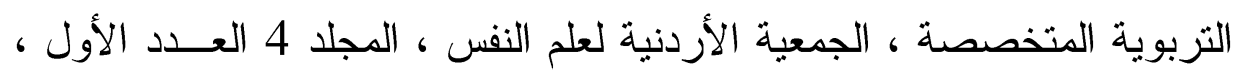

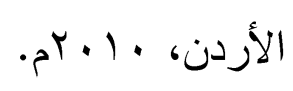

:الصفوف المقلوبة دذخل لخلق بيئة تعليمية شاملة ، مجلة دراسـات التعلـيم 0. زينب محمد خليفة

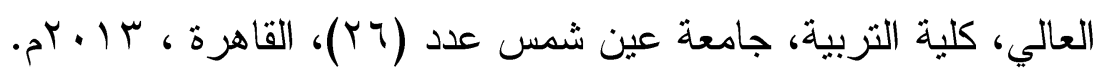

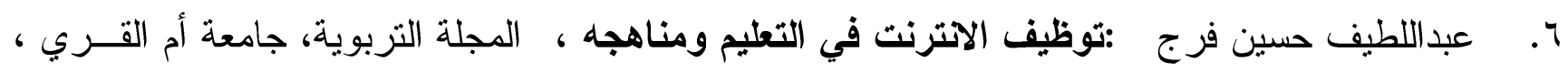

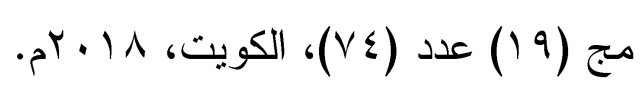

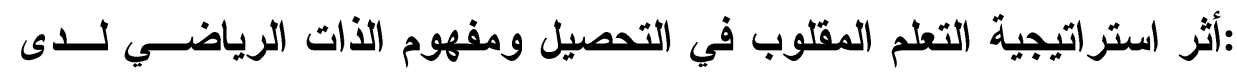
V. الينا سليمان محمود

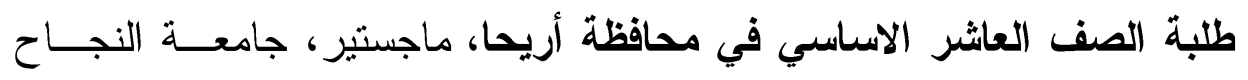




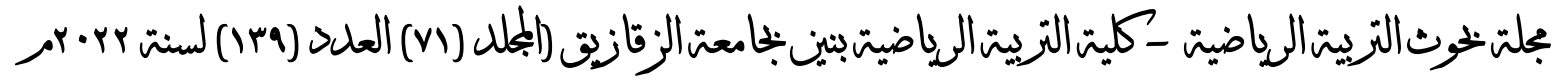

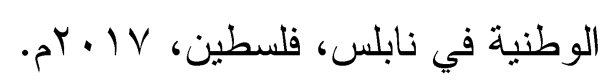

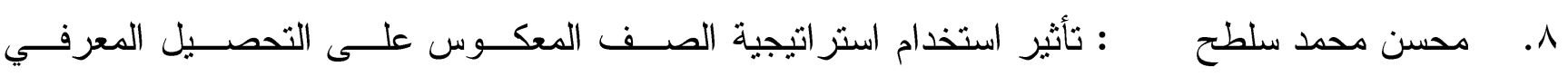

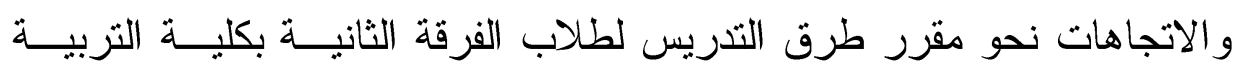

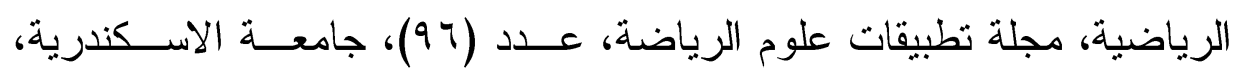

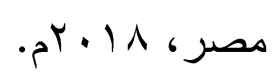

9. محمود محمد محمد :تأثير التعليم عن بعد على المستوى المعرفي والمهاري لمنهاج كرة الســلة،

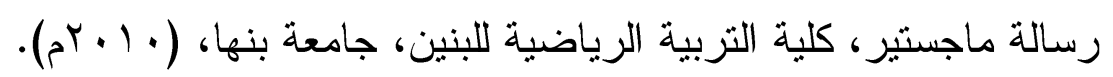

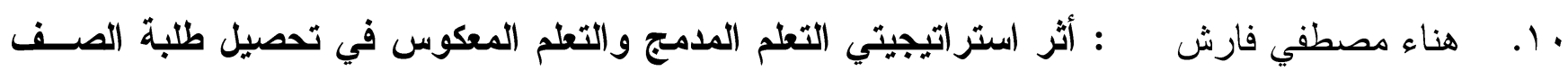

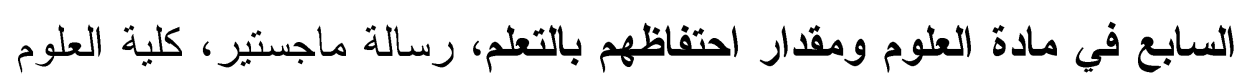

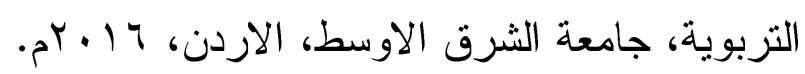

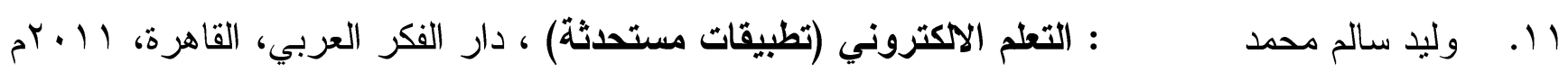
ثانياً : المراجع الأجنيية

12- Crawford : Flipped and blended, using blended faculty Development to steven increase the use of technology among health science faculty ,Arizona state university USA, 2015.

13- Jeremy $\mathbf{F}$ : the effects of the classroom A survey of the research American Strayer Society for engineering education journal 6(2) paer presented at the $12^{\text {th }}$ ASEE Conference \& Exposition, 2008.

14- Johnson : NMC Horizon Report ; Higher Education Edition, Austin . L.W.,\& Texas: The New Media Consortium , 2012.

Renner J.D.

15- Maureen : Inverting the class room: A-Gateway Creating An Inclusive J.Lage, learning Environment, the journal of Economic education Glenn VOL.31.2000.

J.Platt,.

16- Rozinah,J : the use of aflipped classroom to Enhance Engagment and promote Active learning journal of education and practice. 2014.

17- Stayer,J.F : The effects of the classroom flip on the learning environment,A comparison of learning activity in a traditional classroom and flip classroom that used an intelligent tutoring system,Doctoral Dissertation, the ohio statf university, 2008.

18- Toto,R.\& : Flipping the work design in an industrial engineering Nguyen,H. course,processing,39th ASEELIIEE Frontiers in Education 


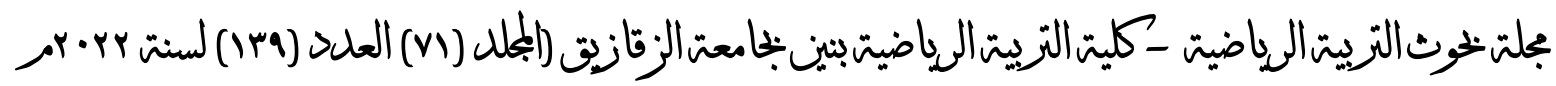

Conferences,San Antonio,Texas,USA. 2009. 